Marta Forc

\title{
Motywy militarne w polskiej propagandzie komunistycznej w latach 1944-1956
}

Niejednokrotnie w historii władza państwowa wielu krajów swoją prawomocność i późniejszą stabilność budowała na gruncie działań zbrojnych i propagandowych (Szulczewski 1972: 51). W dziejach Polski szczególnym odzwierciedleniem tak funkcjonujących rządów był okres PRL, zwłaszcza lata 1944-1956. Dla organizującej się wówczas w Polsce władzy ludowej był to czas niezwykle istotny; czas, w którym polityczna strategia uprawianej propagandy opierała się na programie permanentnej nienawiści i ustawicznej walki o utrzymanie zdobytego panowania. Umacnianiu i stabilizacji zagarniętej przez komunistów władzy nieustannie towarzyszyła atmosfera terroru, strachu i zagrożenia. Realna walka i eliminacja „,wszechobecnego wroga" przekładała się na wszelkie możliwe środki działania. Jasno odzwierciedlają to fakty historyczne okresu 1944-1956. Wtedy to całość rządowych działań w sferze politycznej, społecznej i gospodarczej wspierały organy militarne - wojsko, milicja, Służba Bezpieczeństwa. Również propaganda, nierozerwalnie związana $z$ procesem sprawowania władzy, przesiąknięta była wojenną retoryką i językiem nienawiści.

Już pierwsze posunięcia „władzy ludowej” w powojennej Polsce stanowiły zapowiedź preferowanego przez nią stylu rządzenia. Atmosfera agresywnej propagandy towarzyszyła między innymi ogłoszeniu Manifestu Lipcowego w roku 1944 - komuniści jasno wyrazili w nim swój negatywny stosunek do rządu polskiego na emigracji, który $\mathrm{w}$ dokumencie określili „władzą samozwańcza, władzą nielegalna, [opartą - M. F.] na [...], faszystowskiej konstytucji..." Znamienna jest także $w$ tym czasie

1 http://pl.wikisource.org/wiki/Manifest_Polskiego_Komitetu_Wyzwolenia_Narodo wego; ze strony korzystałam dn. 2 maja 2010 r. 
Motywy militarne w polskiej propagandzie komunistycznej...

stała obecność na ziemiach polskich służb bezpieczeństwa ZSRR oraz Armii Czerwonej. To militarne „wsparcie”, poprzez aktywną eliminację polskich organizacji niepodległościowych, członków Armii Krajowej oraz osób związanych z rządem londyńskim i polskim Podziemiem, ułatwiało komunistom przejmowanie władzy (Roszkowski 2006: 133-134).

Kolejnym krokiem na drodze do pełnej dominacji politycznej było powołanie Rządu Tymczasowego Rzeczpospolitej Polskiej w grudniu 1944 r. Nowy organ był rządem środowisk wyłącznie komunistycznych. Również utworzony pół roku później Tymczasowy Rząd Jedności Narodowej - pozornie koalicyjny - rzeczywistą władzę pozostawiał w rękach komunistów. Decydowała o tym przede wszystkim struktura TRJN, w którym zwierzchnictwo nad Ministerstwem Bezpieczeństwa Publicznego i wojskiem przejęła Polska Partia Robotnicza. Tym samym komuniści otrzymali wszystkie narzędzia umożliwiające stałą kontrolę wszelkich instytucji publicznych, stronnictw politycznych, organizacji społecznych oraz gospodarczych (Roszkowski 2006: 144, 151-153).

O faktycznym zdobyciu politycznego panowania przesądziły: czerwcowe referendum z roku 1946 oraz wybory parlamentarne ze stycznia 1947 r. Obydwa głosowania - poprzedzone intensywnymi kampaniami propagandowymi - stanowity swoistą demonstrację bezkompromisowości komunistów w walce o monopolistyczną władzę. Wyniki zarówno referendum, jak i wyborów zostały sfałszowane, a „niepodważalne zwycięstwo" zapewniła komunistom „wzmożona aktywność” Urzędu Bezpieczeństwa i Milicji Obywatelskiej podczas głosowania oraz jawność głosowania $\mathrm{w}$ wojsku. Wydarzenia te rozpoczęły proces przymusowej stalinizacji Polski, który oznaczał adaptację radzieckich rozwiązań na polu politycznym, gospodarczym i społecznym.

Jednoznacznym symptomem nadchodzących zmian były tendencje zjednoczeniowe $\mathrm{i}$ centralistyczne $\mathrm{w}$ obrębie partii politycznych i organizacji społecznych, które ułatwiały ich permanentną kontrolę. Zaostrzony kurs totalizującej wszystkie wymiary życia partii nie ominął Kościoła katolickiego - walce $\mathrm{z}$ duchowieństwem towarzyszyła czarna propaganda, oskarżająca je o działalność wbrew interesom Polski i współpracę $\mathrm{z}$ „,amerykańskimi imperialistami” (Roszkowski 2006: 176-185). Sowietyzacja intensywnie wkroczyła również w sfery życia kulturalnego, umożliwiając komunistom bezpośrednią ingerencję we wszystkie obszary działalności umysłowej i twórczej. Recepcja zasad „realizmu socjalistycznego" w dziedzinach kultury i nauki oznaczała podporządkowanie ich celom propagandy politycznej. Polityczne ujarzmianie społeczeństwa 
przebiegało równolegle z systemowymi przemianami polskiej gospodarki. Społeczną akceptację zapowiadanych reform komuniści budowali na hasłach odbudowy kraju, poprawy warunków życia i zasiedlenia Ziem Odzyskanych. Sednem strategii gospodarczej było jednak powielenie modelu industrializacji radzieckiej (Roszkowski 2006: 191-196).

Prawnym usankcjonowaniem zaprowadzonego przez komunistów porządku była uchwalona 22 lipca 1952 r. nowa ustawa zasadnicza, która określała Polskę mianem państwa „demokracji ludowej” i oficjalnie zmieniała jej nazwę na Polską Rzeczpospolitą Ludową. Konstytucja znosiła tradycyjny trójpodział władz i urząd prezydenta, zapisy rozdziałów zaś mówiących o prawach i obowiązkach obywateli sankcjonowały swobodną interwencję władz we wszystkie sfery ich życia. W rzeczywistości Konstytucja PRL stanowiła więc legalizację totalitarnych praktyk systemu władzy.

\section{Aparat propagandowy}

Aby państwo, w którym propaganda stanowi jeden z głównych filarów systemu politycznego, mogło skutecznie funkcjonować, musi „wyposażyć się" w odpowiednio zorganizowany aparat propagandowy. Taki, bez wątpienia, był ambicją władz Polski Ludowej. Silnie rozbudowane przez komunistów struktury sprawiały, że

Propaganda przenikała wszystkie dziedziny życia społecznego PRL. Do jej realizacji zaprzęgnięto cały aparat partyjny i państwowy, organizacje społeczne, szkoły wszystkich szczebli i wiele innych instytucji (Kamiński 2004: 13).

Propaganda komunistyczna miała zatem charakter wszechogarniający. Na powszechność i intensywność działań propagandowych pozwalało stworzenie wielu wyspecjalizowanych ośrodków propagandowych, które podzielić można na kierownicze, wykonawcze i wydzielone (Kamiński 2004: 10).

Naczelnym organem kierowniczym w strukturach propagandowych było Ministerstwo Informacji i Propagandy. Instytucjonalizacja propagandy na poziomie Ministerstwa uprawomocniała ją i kształtowała pozytywny odbiór działań propagandowych jako działań podejmowanych 
Motywy militarne w polskiej propagandzie komunistycznej...

w interesie państwa, a nie kierownictwa partyjnego (Kamiński 2004: 10). Podstawowym zadaniem Ministerstwa było opracowywanie wytycznych dla konkretnych akcji propagandowych oraz ich koordynacja i nadzór. Obowiązki resortu znacznie przekraczały jednak realizację zadań propagandowych i odnosiły się również do szeroko zakrojonej misji budowania nowego, powojennego porządku.

Mimo iluzorycznej autonomii Ministerstwo zostało w pełni podporządkowane władzom partyjnym, a niezależność jego działań była pozorna. Jednoznacznie potwierdziła to likwidacja Ministerstwa w roku 1947 i przekazanie jego kompetencji Wydziałowi Propagandy PPR (później PZPR). Tym samym aparat propagandowy formalnie znalazł się w rękach partii rządzącej, która od tego momentu przygotowywała założenia dla podejmowanych kampanii propagandowych (Czyżniewski 2005: 41-52).

Wyznaczane przez pion ideologiczno-propagandowy Komitetu Centralnego zadania realizowały rozległe struktury wykonawcze. Naczelne instytucje stanowiły tu Radiokomitet oraz Robotnicza Spółdzielnia Wydawnicza „Prasa-Książka-Ruch”, jednak PZPR włączała do współpracy wiele innych organizacji (Kamiński 2004: 12). W wymiar wykonawczy polityki propagandowej zaangażowana była administracja państwowa, zwłaszcza Ministerstwo Administracji Publicznej, Ministerstwo Oświaty oraz Ministerstwo Spraw Zagranicznych, odpowiedzialne za propagandę zewnętrzną. Na struktury wykonawcze składały się również wszelkie instytucje polityczne i społeczne, takie jak związki zawodowe, organizacje młodzieżowe, szkoły oraz ośrodki kształcenia ideologicznego członków PZPR (Czyżniewski, 2005: 57-75).

Ostatni segment aparatu propagandowego stanowiły struktury wydzielone. W przeciwieństwie do struktur wykonawczych, nie podlegały one bezpośrednio strukturom kierowniczym. Ich działalność była realizacją wyznaczonej linii polityki propagandowej, odbywała się jednak przy użyciu innych środków (Kamiński 2004: 12). Jedną z instytucji tego typu było Wojsko Polskie, a dokładniej jego pion propagandowo-wychowawczy. Otwarte manifestowanie przez siły zbrojne poparcia dla rządu komunistycznego miało potwierdzać stabilność i trwałość nowej władzy. W akcjach propagandowych uczestniczyły również inne jednostki mundurowe, m. in. milicja i Korpus Bezpieczeństwa Wewnętrznego (Czyżniewski 2005: 59-64). Do struktur wydzielonych zaliczała się także Służba Bezpieczeństwa. Chociaż jej podstawowym zadaniem było podtrzymywanie powszechnej kontroli i terroru, SB miała znaczący wkład 
w działalność propagandową. Dominującą formą jej aktywności była tzw. czarna propaganda - zniesławienia osób lub grup, nieprawdziwe pogłoski, ulotki, oczerniające plakaty czy fałszywe dokumenty. Ważnym elementem tych struktur była ponadto cenzura, czyli Główny Urząd Kontroli Prasy Publikacji i Widowisk, która „zabiegała” przede wszystkim o spójność treści emitowanych $\mathrm{w}$ mediach $\mathrm{z}$ programem politycznym partii (Kamiński 2004: 13).

\section{Cele propagandy komunistycznej}

Silnie rozbudowany aparat propagandowy świadczy o docenianiu znaczenia propagandy jako narzędzia utrzymania dominującej pozycji. Istotną rolę propagandy $\mathrm{w}$ procesie komunikacji ze społeczeństwem odzwierciedlają również wypowiedzi przedstawicieli władz komunistycznych. Potwierdza to miedzy innymi biuletyn szczecińskiego KW PPR, którego autorzy stwierdzają: „Przed nami stoi dziś bardzo poważne zagadnienie przeobrażenia psychiki ludzi wychowanych pod działaniem obcych i wrogich czynników" (Czyżniewski 2005: 8). Wypowiedzi utrzymane $\mathrm{w}$ tym tonie dają wyobrażenie tego, jak poważne były zadania, których realizację władza ludowa powierzała propagandzie.

Zakrojona na szeroką skalę propaganda obejmowała wszystkie sfery życia politycznego, gospodarczego, społecznego i kulturalnego. Pożądane przez władze komunistyczne postawy Polaków wyrażać miały całkowite podporządkowanie wobec nowego rządu. Propaganda była formą "wychowywania" - popularyzowała nowe wzorce zachowań i agitowała w bieżących sprawach - przy okazji wyborów czy w sytuacjach kryzysów gospodarczych.

Budowa trwałej akceptacji dla nowej władzy wymagała jej społecznej legitymizacji, dla osiągnięcia której komuniści opierali się głównie na propagandzie. Konstytutywne dla urzeczywistnienia tego celu było przekonanie społeczeństwa o stabilnej pozycji nowej władzy, o tym, że jest ona bezalternatywna, a więc wszelki opór wobec niej pozbawiony jest sensu. Innym strategicznym z punktu widzenia komunistów celem była budowa własnego wizerunku jako władzy legalnej, dysponującej pełnią praw do reprezentacji interesów narodu polskiego (Czyżniewski 2005: 10). 
Motywy militarne w polskiej propagandzie komunistycznej...

Całość działań skierowana była na zbudowanie w Polakach nowego rodzaju świadomości - świadomości zaplanowanej przez komunistów funkcjonującej i reagującej w określony sposób. Solidarność i poczucie wspólnoty narodowej wśród „homo sovieticus” miały opierać się na zdefiniowanym przez komunistów katalogu wartości, jakie stanowić miały m. in. partia, przyjaźń polsko-radziecka i socjalizm. Efektem wysiłków wkładanych w budowę "nowego człowieka” miałoby być zaakceptowanie „Polski w nowym, nieznanym dotąd kształcie” (Czyżniewski 2005: 8). Do najefektywniejszych technik propagandowych, które służą kształtowaniu pożądanych postaw i budowie wspólnoty narodowej, według Floriana Znanieckiego zaliczają się: mit wspólnego pochodzenia i jedności rasowej, kult bohaterów, mit wspólnego wroga oraz przywiązanie do ojczystego kraju (1990: 124) Propaganda komunistyczna chętnie korzystała $\mathrm{z}$ wymienionych technik, często odwołując się w emitowanych przekazach do poszczególnych mitów.

Kreacja bohatera polega na propagowaniu w danej grupie społecznej określonych wartości, uosobionych w heroizowanej postaci. Bohaterem może być obrońca narodu, jego wybawca lub władca. Początkowo kult bohatera przywoływał legendarne bądź historyczne wzory osobowe, jednak w czasach najnowszych propaganda częściej sięga do kultu bohaterów żyjących (Znaniecki 1990: 128-129). W propagandzie władzy ludowej kult bohaterów wojennych i politycznych zaznaczył się bardzo wyraźnie. Najbardziej oczywistym przykładem był - szeroko rozpowszechniany we wszystkich krajach bloku ZSRR - kult Stalina. Również żołnierz polsko-radzieckich sił zbrojnych często prezentowany był jako wybawca i obrońca narodu. Ze względu na prowadzoną politykę gospodarczą promowanymi postawami były także wzory robotników i chłopów, których praca w propagandzie nosiła znamiona bohaterstwa.

Tkwiąca w grupach społecznych naturalna potrzeba posiadania własnego terytorium jako wyłącznej własności jest podstawą kolejnego mitu budującego poczucie wspólnoty i odrębności narodowej. Pojęcia: "terytorium narodowe", „kraj ojczysty", „kraj naszych ojców” odzwierciedlają wartości nie tylko ekonomiczne, lecz również moralne czy wręcz religijne. Posiadana własność uzasadnia prawo do jej ochrony, stąd wyłączność terytorialną od zawsze wspierały rządy polityczne i wojsko. Hasła obrony granic państwowych i obszaru zamieszkanego przez swoich obywateli niejednokrotnie uzasadniały imperialistyczne zapędy przywódców politycznych i wypełniały treść propagandowych komunikatów (Znaniecki 1990: 139-144). Również propagandziści komunistyczni - poprzez 
odwołania do mitu „kraju ojczystego" - „uzasadniali zasadność" terytorialnych zmian na ziemiach polskich, jakich, wbrew woli Polaków, dokonali alianci zgodnie z inspiracjami Stalina.

Kolejnym silnie integrującym społeczność czynnikiem jest poczucie zagrożenia. Mit obecności wspólnego wroga wzmacnia solidarność, jednoczy grupę i mobilizuje ją do podjęcia działań obronnych. Elity rządzące często odwołują się do potrzeby walki z rzeczywistym bądź potencjalnym niebezpieczeństwem (Znaniecki 1990: 144-148). Motyw wroga w propagandzie komunistycznej wykorzystywany był najczęściej, zwłaszcza w okresie bezpośrednio powojennym, naznaczonym koniecznością nieustannej walki o władzę. Rozbudowana przez władzę ludową kategoria wroga obejmowała zagrożenie wewnętrzne i zewnętrzne, realne i potencjalne. Kampanie propagandowe wymierzone w szeroko definiowanego wroga były wyjątkowo agresywne, przesiąknięte językiem nienawiści.

\section{Analiza plakatów}

Przykłady zastosowań opisywanych przez Znanieckiego technik propagandowych ujawniły się na plakatach komunistycznych. Jako jedna $\mathrm{z}$ głównych, a zarazem jedna $\mathrm{z}$ najprostszych form przekazu treści propagandowych, plakat należał do podstawowych środków wyrazu w politycznej propagandzie wizualnej władz ludowych.

Analiza przykładowych posterów z okresu 1944-1956 pozwala wskazać zastosowanie opisanych wcześniej technik oraz sposób, w jaki plakat służył propagandzie komunistycznej i jak - dzięki jego użyciu twórcy systemu osiaggali wyznaczone cele. Zaprezentowana poniżej analiza została przeprowadzona na zbiorze 28 plakatów, będących przykładami propagandy komunistycznej z lat 1944-1956. Wybór konkretnych posterów umożliwiły przede wszystkim zasoby internetowe ${ }^{2}$. Kryterium włączenia plakatu do badanego zestawu stanowiła częstotliwość jego występowania na dostępnych witrynach. Wybrany w ten sposób zestaw posterów uzupełniły dodatkowo prace $\mathrm{z}$ katalogu Żadło propagandy PRL-u 1945-1956, wydanego przez Muzeum Plakatu w Wilanowie.

${ }^{2}$ Grafiki pobrałam 7 lutego 2010 r., korzystając głównie ze stron: http://chomikuj.pl/ zamorski/*e2*99*a0Plakaty*e2*99*a0/Plakat+polityczny+PRL oraz http://www.prl.cba.pl/ plakaty.html. 
W pracy nad zgromadzonym materiałem wykorzystana została metoda czteroetapowej analizy treści. Kolejne fazy analizy pozwalają na opisanie wybranego zestawu prac na podstawie kategorii wyodrębnionych w wyniku wstępnej analizy materiałów. Wyróżnione kategorie, by mogły posłużyć jako uniwersalne narzędzie analizy zebranego materiału, stanowią odzwierciedlenie motywów i wątków, które najczęściej powtarzają się na plakatach. W ten sposób opracowane kategorie analityczne porządkują pracę nad materiałem badawczym, pozwalają na sformułowanie wniosków oraz pomagają zbudować własne refleksje (Ferenc 2007: 10-12). Kategorie użyte w poniższej analizie, to: 1) wiek i płeć osób przedstawianych na plakatach, 2) rola społeczna i związany z nią sposób prezentacji postaci oraz przypisywane jej atrybuty, w zależności od pełnionej funkcji społecznej, 3) wykorzystanie symboli, 4) sposób prezentowania wroga, 5) sposób prezentacji władz komunistycznych, 6) relacja tekstu i obrazu na plakatach, 7) obecność koloru.

Propaganda komunistyczna w przekazach wizualnych sięgała najczęściej po wizerunki ludzi. Sposób ich prezentacji był na ogół realistyczny, choć w przypadku czarnej propagandy, wymierzonej we wroga, preferowano formy karykaturalne. Warto w tym miejscu dodać, że plakaty propagandowe stanowiły klasyczne przykłady sztuki socrealizmu, której ramy określała stalinowska ideologia. W związku z tym kompozycja posterów miała charakterystyczne dla realnego socjalizmu cechy formalne. Wysunięci na pierwszy plan bohaterowie plakatów byli najczęściej wystylizowanymi przedstawicielami klasy pracującej - robotniczej i chłopskiej. Zastosowanie „żabiej perspektywy” nadawało postaciom monumentalnych wymiarów, znamienna była również uniformizacja ich strojów. Zarówno ujednolicenie, jak i faworyzacja określonych warstw społecznych służyły propagowaniu wartości socjalistycznych, takich jak równość i sprawiedliwość społeczna (Izdebski 2000: 9).

Na plakatach pojawiali się przedstawiciele obu płci, zdecydowanie przeważali jednak mężczyźni, prezentowani najczęściej w rolach rolnika (plakat 1), robotnika (plakaty 1, 2) i żołnierza (plakat 3). Mężczyźni dominowali również na plakatach odnoszących się treściowo do kwestii politycznych, ponieważ to dla nich zarezerwowana była sfera ówczesnego życia politycznego. Wiek postaci przedstawianych $\mathrm{w}$ propagandzie komunistycznej określić można jako produkcyjny - tego wymagały stawiane im zadania - stąd wojskowych czy robotników reprezentują zazwyczaj młodzi i silni mężczyźni. 


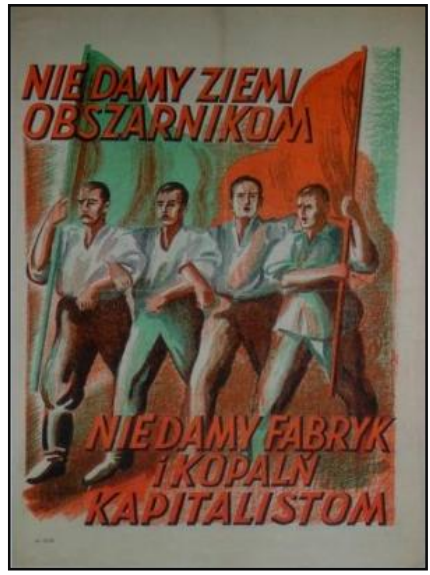

Plakat 1

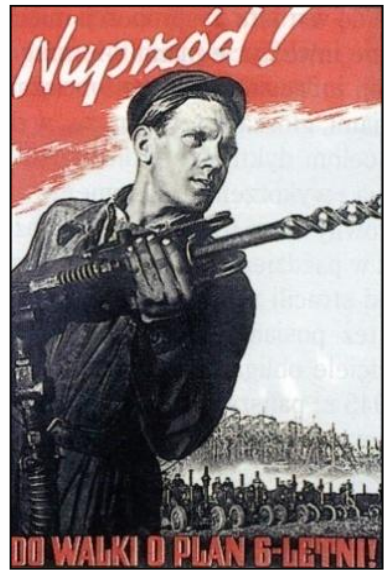

Plakat 2

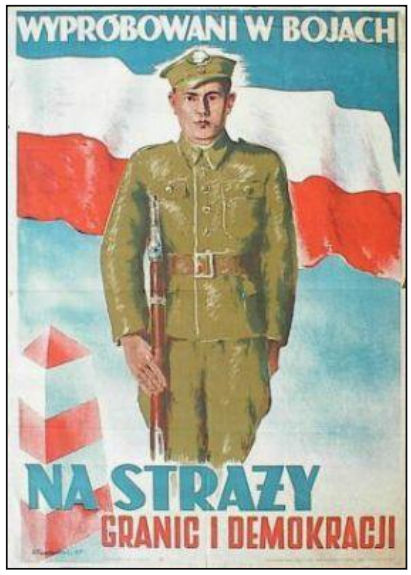

Plakat 3

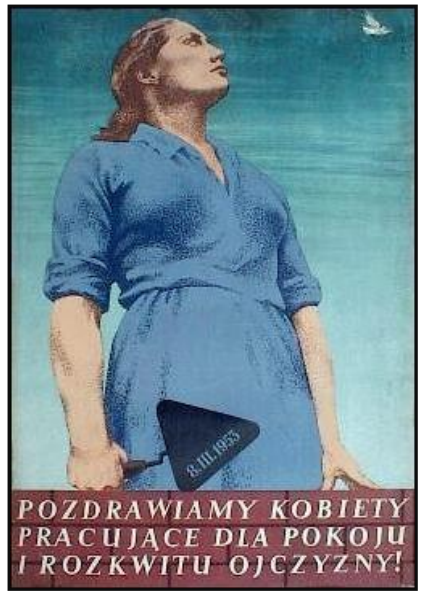

Plakat 4

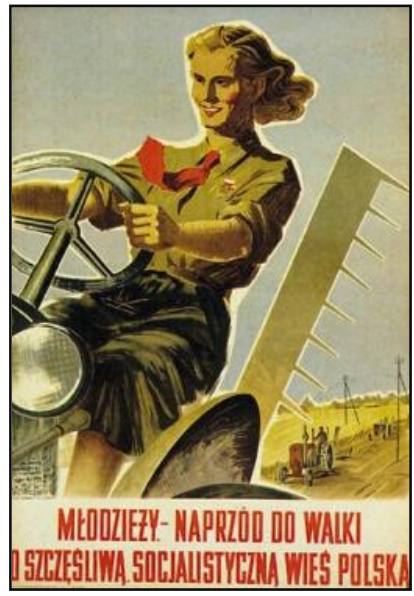

Plakat 5

Na plakatach, choć rzadziej, pojawiają się również wizerunki kobiet. Powojenna praca na rzecz nowego porządku społecznego oraz przyjęta polityka gospodarcza miały przecież angażować cały naród. Silnie propagowana była aktywizacja zawodowa kobiet, która dodatkowo zrywała ze stereotypowym podziałem na prace typowo męskie i żeńskie. Odzwierciedlają to plakaty zaprezentowane na obrazach 4 i 5 - kobiety zostały na nich przedstawione $\mathrm{w}$ trakcie wykonywania czynności utożsamianych z pracami przeznaczonymi dla mężczyzn. Na jednym z posterów młoda kobieta, z kielnią w ręku, jest przygotowana do ciężkiej, robotniczej pracy 
na rzecz „Pokoju i rozkwitu ojczyzny” (plakat 4). Kolejnym przykładem jest plakat prezentujący dziewczynę na traktorze, która z uśmiechem na twarzy podejmuje trud powierzonych jej zadań (plakat 5).

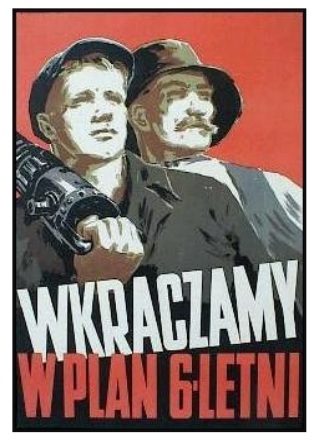

Plakat 6

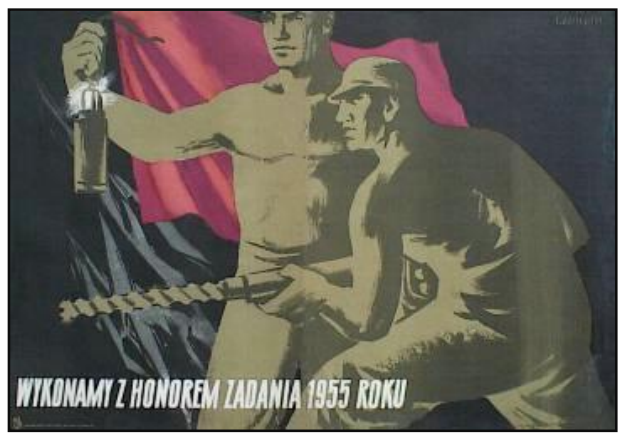

Plakat 7

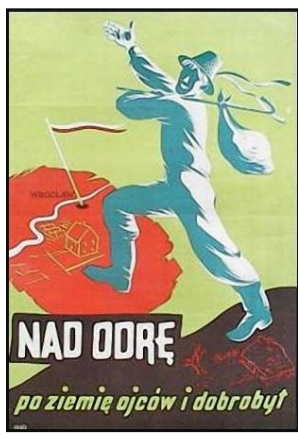

Plakat 8

Trwałe zmiany w strukturze społecznej były jednym z celów polityki komunistycznej, dlatego kolejną kategorią badawczą dla wybranego zestawu plakatów była kategoria roli społecznej. Założenia systemu socjalistycznego promowały określony układ ról społecznych, w którym robotnicy i chłopi byli grupami uprzywilejowanymi (plakaty 1, 2, 4, 6, 7, 8). Ta nobilitacja znalazła odzwierciedlenie na plakatach propagandowych, których częstym tematem były sojusz robotniczo-chłopski oraz jego znaczenie dla narodu (plakat 6).

Klasy robotnicza i chłopska, jako trzon Polski Ludowej, przedstawiane były najczęściej w kontekście mobilizacji do konkretnych zadań. To tym grupom władze komunistyczne „powierzały” realizację planów gospodarczych, co jasno komunikowały liczne plakaty propagandowe z okresu 1944-1956 (plakaty 2, 4, 6, 7). Grafiki prezentowały zazwyczaj podobizny młodych, zdolnych do pracy mężczyzn, których robotniczy status identyfikowały elementy stroju oraz charakterystyczne narzędzia. Postawa robotników wyrażała entuzjazm i gotowość do działania (plakat $2,6,7)$. Faworyzująca status robotniczy propaganda komunistyczna, poprzez wizualne komunikaty, popularyzowała aktywność zawodowa, określony styl życia i działania.

Z wielu powodów rola żołnierza była kolejna, obok robotnika i chłopa, funkcją społeczną strategicznie ważną dla realizacji dążeń władz ludowych. Po pierwsze - przejmowanie władzy przez komunistów odbywało się $\mathrm{w}$ warunkach niezakończonej wciąż wojny oraz rywalizacji z patriotyczną opozycją polityczną i wojskową. Arbitralne ustalenia 
Wielkiej Trójki oraz obecność na ziemiach polskich wojsk radzieckich potęgowały napięcie i niechęć Polaków wobec konstytuującego się porządku. Odpowiedzią na wzmagający się niepokój i niepewność była m. in. seria plakatów "oswajających" z obecnością wojskowych sił radzieckich i sprzymierzonym Wojskiem Ludowym. Drugim powodem, dla którego rola żołnierza miała być tak istotna, była wytwarzana przez komunistów atmosfera nieustannego zagrożenia, które wymagało stałej mobilizacji i gotowości do walki.

Bezpośrednio w okresie powojennym żołnierz zjednoczonych wojsk polsko-radzieckich przedstawiany był jako wyzwoliciel narodu oraz gwarant pokoju i stabilności (plakaty 9, 11). Postaci wojskowych na plakatach propagandowych wyrażały dumę z pełnionej służby, a poważne oblicza świadczyły o ich randze oraz odpowiedzialności, jaka na nich spoczywa (plakaty 3,11 ). Poprzez kreowanie pozytywnego wizerunku Armii Ludowej propagandziści nie tylko tłumaczyli zasadność jej powszechnej obecności, lecz również wzywali do zasilania jej szeregów. Żołnierz - „radość i duma rodziców” (plakat 10) - był nowym władzom niezbędny dla utrzymania dominującej pozycji politycznej oraz wprowadzanego porządku społecznego.

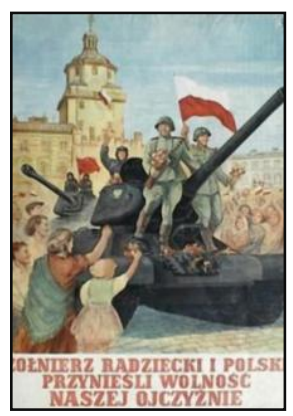

Plakat 9

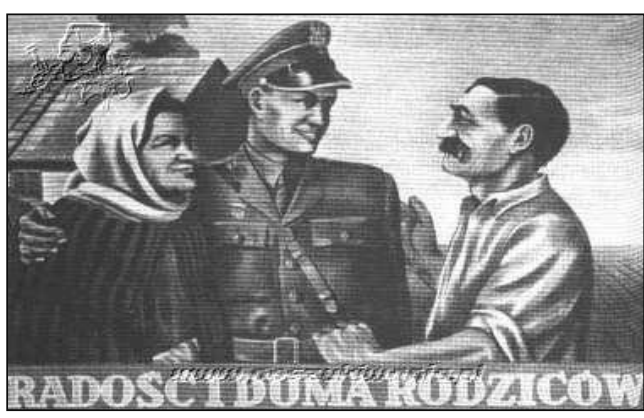

Plakat 10

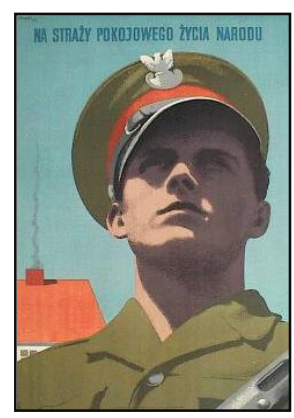

Plakat 11

Grupa plakatów opisanych przez pryzmat kategorii roli społecznej wpisuje się $\mathrm{w}$ propagandowy mit bohaterów, o którym pisał Znaniecki. W tym przypadku heroizowanymi postaciami są chłopi, robotnicy i żołnierze, którzy na plakatach proponują współczesne odbiorcom wzory zachowań. Sposób prezentacji postaci uwzniośla ich role społeczne i kreuje na bohaterów dnia codziennego, z których postawą warto się identyfikować. Nobilitacja tych grup oznaczała jednoczesną deprecjację elit intelektualnych, których wiedza i niezależność światopoglądowa 
zagrażały realizacji wizji socjalistycznego państwa. W związku z tym to praca robotnika oraz rola żołnierza przedstawiane były jako najlepsze drogi rozwoju zawodowego, jako szansa awansu społecznego, umożliwiająca ludności wiejskiej migrację do miast (plakat 10).

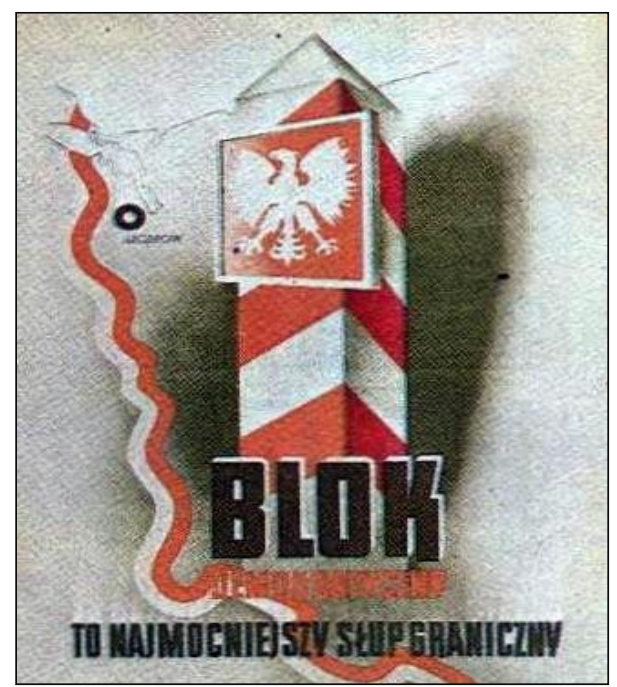

Plakat 12

W konstrukcji przekazów wizualnych często wykorzystywanym elementem są wszelkiego rodzaju symbole, występujące bądź to samodzielnie, bądź jako uzupełnienie bardziej rozbudowanych obrazów. Z tego względu to symbol był kolejną kategoria, opierając się na której analizowano zebrany materiał badawczy.

$\mathrm{Na}$ plakatach komunistycznych odwołanie do symboliki polegało głównie na używaniu barw narodowych oraz wykorzystywaniu takich elementów identyfikacji, jak flaga i godło. Najczęściej pojawiającym się symbolem była flaga biało-czerwona, której obecność odzwierciedlała idee patriotyzmu i jedności narodowej oraz komunikowała o działaniu $\mathrm{w}$ interesie Polski (plakaty 3, 9, 12). Barwy narodowe pojawiały się na plakatach o różnej treści propagandowej. Komuniści, jeszcze przed całkowitym przejęciem i ustabilizowaniem władzy, w celu zdobycia większego poparcia i zaufania często posługiwali się polskimi symbolami narodowymi. Kolory flagi jako kontur zachodniej granicy Polski oraz przytwierdzone do słupa granicznego godło - stały się na plakacie wizualizacją politycznego programu Bloku Demokratycznego (plakat 12). 
W ten sposób założenia programowe ugrupowań skupionych w Bloku zostały zaprezentowane jako walka w obronie żywotnych interesów narodowych, za jakie uważano utrwalenie powojennych granic. $\mathrm{Na}$ tym plakacie odwołanie się do terytorialnej własności grupowej jest jednocześnie przykładem zastosowania $\mathrm{w}$ propagandzie mitu wspólnej ziemi i konieczności ochrony jej nowej granicy. Forma plakatu, zazwyczaj sprzężona z przekazem słownym, często posługiwała się barwami narodowymi również przy stylizacji wizualnej sloganów i haseł. Przykładem był plakat Wkraczamy w plan sześcioletni (plakat 6), na którym kolorystyka i układ tekstu nawiązywały do flagi biało-czerwonej. Polskiej fladze na plakacie często towarzyszy czerwony sztandar ZSRR (plakat 9). W ten sposób propagowana była przyjaźń polsko-radziecka, którą prezentowano jako jedną z największych wartości - gwaranta dobrobytu, pokoju oraz bezpieczeństwa. Plakaty politycznej propagandy władz ludowych sięgały po symbol także w celu jasnego wskazywania wroga. Wielokrotnie pojawiającym się znakiem była swastyka - państwowy symbol III Rzeszy (plakaty 13, 17, 19). Użycie tego emblematu, tak jednoznacznie kojarzonego ze zbrodniami niemieckiego nazizmu, piętnowało oznaczane nią postacie i w oczywisty sposób budziło w odbiorcach negatywne emocje.

Najczęściej wykorzystywaną techniką propagandową komunistów, zwłaszcza w okresie historycznym, z którego pochodzą analizowane plakaty, był mit wszechobecnego wroga. Lata 1944-1956 były czasem przejmowania, kształtowania i umacniania władzy ludowej w powojennej Polsce, stąd walka z przeciwnikiem, poza jego fizyczną eliminacja w dużej mierze odbywała się w sferze działań propagandowych. Na tej płaszczyźnie możliwe było przede wszystkim określenie i wskazywanie nieprzyjaciela oraz jego deprecjacja $\mathrm{w}$ oczach społeczeństwa. Rozległa kategoria „wroga” obejmowała opozycję polityczną i środowiska Polski Podziemnej, a także cały świat tzw. zachodniego imperializmu, w sferze ideologii - kapitalizm. Podsycanie atmosfery powszechnego zagrożenia znalazło swoje odzwierciedlenie na plakatach propagandowych, które $\mathrm{w}$ znacznym stopniu służyły właśnie walce $\mathrm{z}$ szeroko rozumianym wrogiem politycznym i klasowym.

Plakaty wymierzone w opozycję polityczną wiązały się bezpośrednio z okresami wyborczymi. Tak było np. przed referendum w roku 1946, kiedy możemy zaobserwować liczne plakaty propagujące głosowanie zgodnie z ideą komunistyczną (słynne ",3 3 tak”) i jednocześnie krytykujące przeciwne postawy środowisk opozycyjnych. 


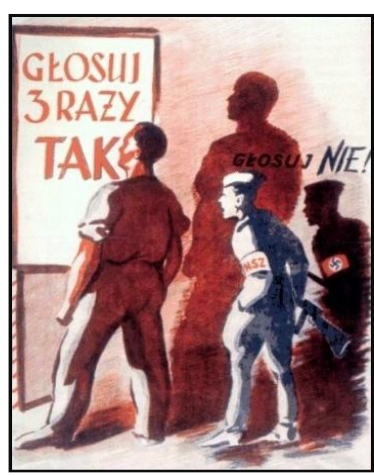

Plakat 13

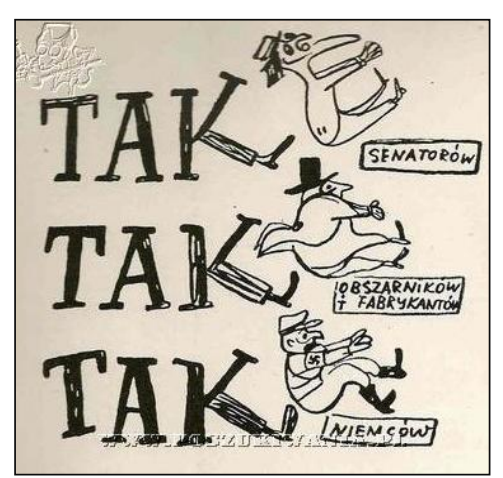

Plakat 14

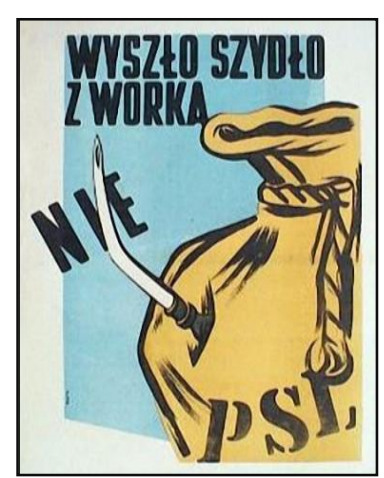

Plakat 15

Wrogiem w walce o hegemoniczną władzę polityczną była na plakacie politycznym między innymi organizacja Narodowych Sił Zbrojnych, której krytyczne stanowisko wobec programu komunistów utożsamione zostało z orientacją faszystowską. Na plakacie opaska symbolizująca przynależność do NSZ, na cieniu postaci ją noszącej, przedstawiona została jako swastyka - symbol niemieckich nazistów (plakat 13). Autor plakatu przedstawił postacie, kontrastując ich wizerunki ze sobą. Mężczyzna zwrócony ku hasłu „Głosuj 3 razy tak” to rosły, silny mężczyzna. Ubranie sugeruje, że jest przedstawicielem klasy robotniczej, a więc klasy „wybranej” przez władze ludowe, stanowiącej fundament i przyszłość socjalistycznej Polski. Działacza NSZ cechuje z kolei drobniejsza postura, jest przedstawiony jako ten słabszy. Jego nawoływanie "Głosuj NIE!” jest „mąceniem” w głowie i zachętą do błędnego postępowania. Rzeczywiste intencje demaskuje cień: opaska symbolizująca przynależność do NSZ przedstawiona została jako swastyka - symbol nazistów. Cień robotnika nie ujawnia ukrytych zamiarów - jest "czysty". Jak podaje Carl Gustav Jung, cień jako archetyp jest przepełniony treścią której sobie nie uświadamiamy, ale którą w bardzo emocjonalny sposób odczuwamy. Cień stanowi gorszą, ciemną stronę charakteru; w sferze tej ujawniają się skrywane, negatywne cechy. Realizacja archetypu cienia, a więc akceptacja tej płynącej z nieświadomości wiedzy o nim, jest równoznaczna z uznaniem ciemnych aspektów osobowości za rzeczywiste (Jung 1976: 65-68). Odwołując się do cienia, twórcy plakatu chcieli więc zdemaskować prawdziwe (w ich mniemaniu) intencje polskich środowisk niepodległościowych i zdyskredytować je w oczach społeczeństwa. 
W podobny sposób propaganda komunistyczna odnosiła się do stanowiska reprezentowanego przed referendum przez stronnictwo PSL. Kampania „ludowców” promująca głosowanie na „nie” była przedstawiana jako przysłowiowe "szydło”, które „wyszło z worka” (plakat 15). Jasna i prosta definicja przeciwnika pojawia się na plakacie 14 - tu akcja „3 x tak" została symbolicznie przedstawiona jako program walki ze zbędnym, zdaniem komunistów, senatem, klasą "obszarników i fabrykantów" oraz niedawnym okupantem - Niemcem.

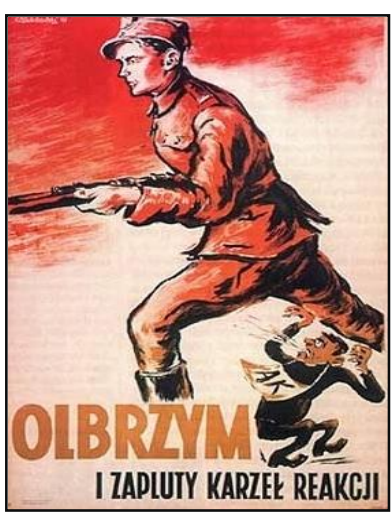

Plakat 16

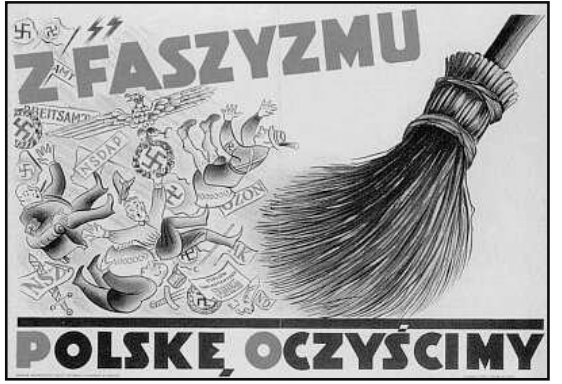

Plakat 17

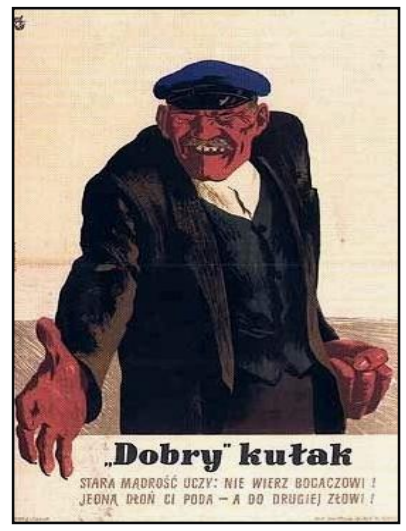

Plakat 18

Prezentacja wroga w komunistycznej propagandzie wizualnej wskazywała i określała go w bardzo jednoznaczny sposób. Plakaty 16, 17 i 18 obrazują kolejne grupy nieprzyjaciół Polski Ludowej. W oczach nowej 
władzy zagrożenie stanowiły siły Armii Krajowej, której reprezentant został przedstawiony na plakacie jako „zapluty karzeł reakcji” (plakat 16). Działacza AK karykaturalnie zilustrowano jako małą i zgarbioną postać, o nieprzyjemnym wyrazie twarzy. Temu ośmieszającemu i nieprzyjemnemu $\mathrm{w}$ odbiorze wizerunkowi przeciwstawiono obraz rosłego i silnego żołnierza wojsk ludowych. Kolejną wrogą grupę stanowili faszyści, do których, poza Niemcami, autor plakatu zaliczył również formacje takie jak Armia Krajowa, OZON, Narodowa Demokracja czy Narodowe Siły Zbrojne (plakat 17). Organizacje Polski Podziemnej i ugrupowania polityczne opozycyjne wobec komunistów zostały na plakacie zrównane z faszystami III Rzeszy, wszystkich zaś razem przedstawiono jako śmieci, z których nowe władze „Polskę oczyszczą". Propaganda polityczna napiętnowała również tzw. kułaków, czyli właścicieli dużych gospodarstw rolnych. Kułak na plakacie propagandowym to ubrany „po pańsku” osobnik, o złośliwym i nieprzyjaznym wyrazie twarzy - wyzyskiwacz chłopów i wróg proletariatu (plakat 18). Jego charakterystyki dopełniał podpis pod rysunkiem: „Stara mądrość uczy: nie wierz bogaczowi! Jedną rękę ci poda - a do drugiej złowi!"

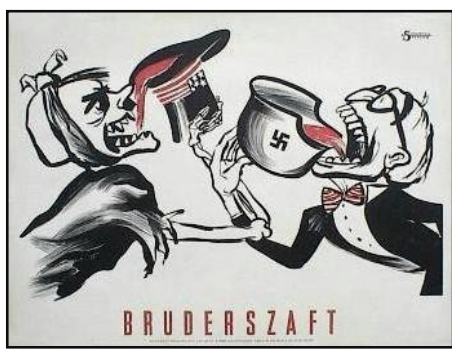

Plakat 19

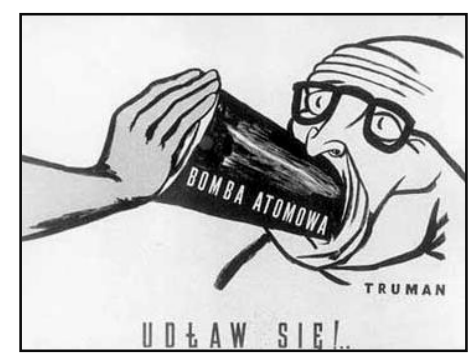

Plakat 20

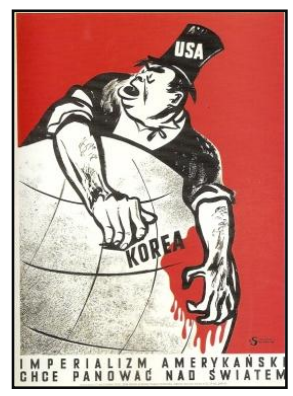

Plakat 21

Intensywne działania propagandowe władz ludowych wymierzone były w "zachodni imperializm”, którego oczywistym przedstawicielem były Stany Zjednoczone. Kampania skierowana przeciwko polityce gospodarczej i ustrojowi USA prowadzona była na wielu płaszczyznach i przybierała różne formy. Krytyka ta znalazła swoje odzwierciedlenie również na plakatach, na których często pojawiała się silnie przerysowana postać prezydenta USA Harrego Trumana. Jedna z karykatur przedstawiała go „w uścisku ze śmiercią" - Truman w przyjacielskim toaście brata się z poległym na wojnie nazistą (plakat 19). W krytyce Stanów Zjednoczonych propagandziści odwoływali się również do faktu posia- 
dania i użycia przez USA bomby atomowej podczas II wojny światowej. Plakaty przypominały o istnieniu realnego zagrożenia, jakie stanowiła broń nuklearna i jednocześnie wyrażały dezaprobatę wobec prowadzonej przez USA polityki. Symbolizująca blok komunistyczny czerwona ręka wpychała bombę w usta Trumana, a przekaz wizualny uzupełniało hasło „Udław się!” (plakat 20). W propagandzie komunistycznej krytyka świata zachodniego bardzo często odwoływała się również do sloganu „wrogiego imperializmu". Mocarstwowe aspiracje Ameryki piętnował plakat 21. Jego autor zilustrował imperialistyczną politykę Stanów Zjednoczonych, uosabiając państwo pod karykaturalnie przedstawioną postacią mężczyzny, który zachłannym gestem zawłaszczał kolejne części globu, chcąc rozszerzyć swoją dominację na coraz nowe obszary świata. Plakat miał na celu przekonanie odbiorców o tym, że ekspansjonistyczne zapędy USA były zagrożeniem także dla Polski.

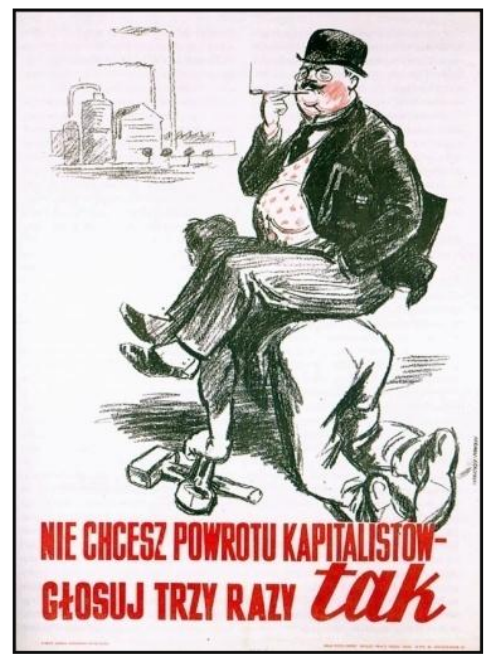

Plakat 22

Wobec socjalistycznej wizji państwa, opartej na politycznym centralizmie oraz nacjonalizacji przemysłu i rolnictwa, naturalnym wrogiem władz komunistycznych był kapitalizm. Na plakacie propagandowym (plakat 22) kapitalista przedstawiany był jako otyły, dobrze ubrany bogacz, niesiony na plecach przez robotnika. To symboliczne pokazanie relacji „kapitalista - pracownik” było odzwierciedleniem uciemiężenia i wyzysku, jakimi prywatni właściciele kierowali się w celu maksymalizacji własnego majątku. Walka z kapitalizmem została tu połączona z kam- 
panią poprzedzającą referendum z roku 1946. Według wyjaśniającego grafikę podpisu, „powrót kapitalistów” był zagrożeniem, przed którym ustrzec może tylko zwycięstwo robotniczych ugrupowań PPR i PPS.

Plakaty skierowane przeciwko wrogom obfitują w karykaturalne i szydercze formy ich prezentacji. Groteskowy sposób przedstawienia deprecjonuje kolejne grupy już w warstwie wizualnej. Plakaty obrazują i utrwalają stereotypy - zachłannego imperialisty (plakat 21), bogatego kapitalisty żerującego na krzywdzie robotników (plakat 18, 22), czy zdradzieckiej opozycji (plakaty 13, 15, 16, 17). Przejaskrawione wizerunki i karykatury wrogów mają za zadanie budzić w odbiorcach niechęć, negatywne emocje i złe skojarzenia.

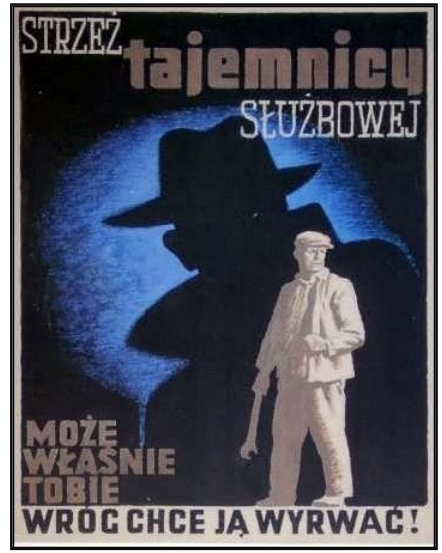

Plakat 23

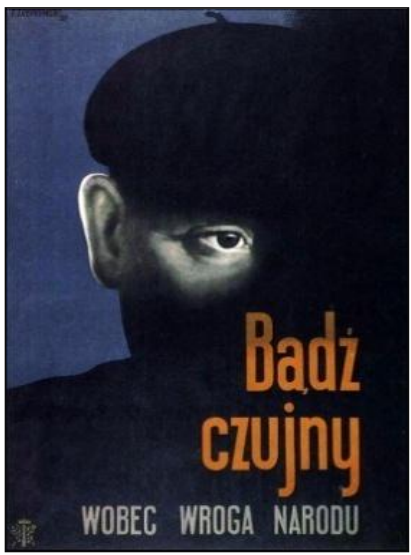

Plakat 24

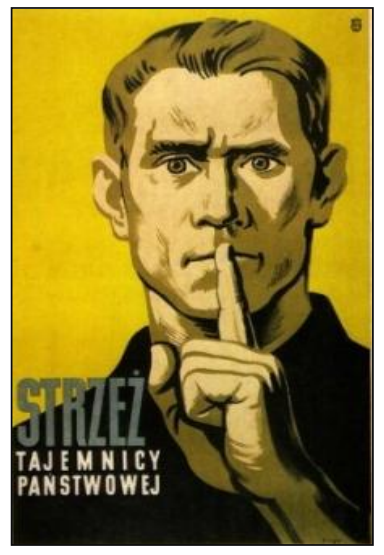

Plakat 25

Atmosferę wszechobecnego niebezpieczeństwa i czyhających wokół nieprzyjaciół podsycały nie tylko plakaty jednoznacznie definiujące agresora. W propagandzie komunistycznej wróg narodu czyha wszędzie, stąd liczne plakaty nawołujące do czujności, obserwacji i postawy wyczulenia na potencjalne zagrożenia (plakaty 23, 24, 25). Wytwarzana w ten sposób potrzeba obrony przed agresorem skupiała wokół wspólnej z nim walki. Utrzymywanie i podsycanie nastroju nieustannego zagrożenia uzasadniało również stałą militaryzację kraju - powszechną obecność wojsk, milicji oraz Służb Bezpieczeństwa. Tym samym ułatwiało komunistom permanentną kontrolę nad społeczeństwem.

Propaganda komunistyczna w dużej mierze koncentrowała się na deprecjacji wroga, nie oznacza to jednak, że pomijała kwestie korzystnego obrazu partii rządzącej oraz relacji ze Związkiem Radzieckim. Wobec 
zależności od ZSRR, w jaką Polska została uwikłana w ramach powojennego ładu narzuconego przez układ jałtański, promocji wymagała zwłaszcza „przyjaźń" polsko-radziecka. Przekonanie społeczeństwa polskiego o przychylności Stalina - niedawnego agresora - było poważnym zadaniem propagandowym, $\mathrm{w}$ ramach realizacji którego pojawiły się plakaty propagujące sojusz z ZSSR. Szeroko rozpowszechniany we wszystkich krajach należących do bloku ZSRR był także kult Stalina jako przywódcy "światowego proletariatu” oraz jednostki wybitnej. Odzwierciedlają to plakaty 27 i 28, prezentujące "wodza" i sławiące jego "dzieło". Innym przykładem może być plakat przedstawiający postaci Stalina i Bieruta, będący jednocześnie kolejnym zastosowaniem w propagandzie mitu bohaterów narodowych (plakat 26). W socjalistycznej Polsce aura bohaterstwa otaczała również Bieruta - „opiekuna i ojca narodu”. Na plakacie dostojnie zaprezentowani zwierzchnicy "sojuszniczych" państw stoją na tle flag polskiej i radzieckiej, w oddali zaś widoczny jest Pałac Kultury i Nauki - "dar narodu radzieckiego dla narodu polskiego". Napis na plakacie wskazywał przymioty partnerstwa polsko-radzieckiego pokój, niezawisłość i szczęśliwą przyszłość.

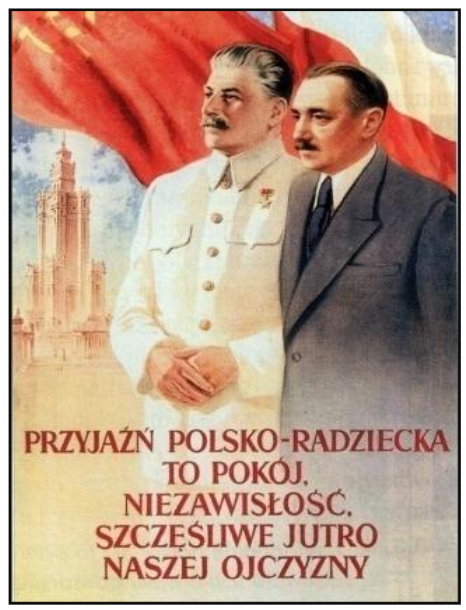

Plakat 26

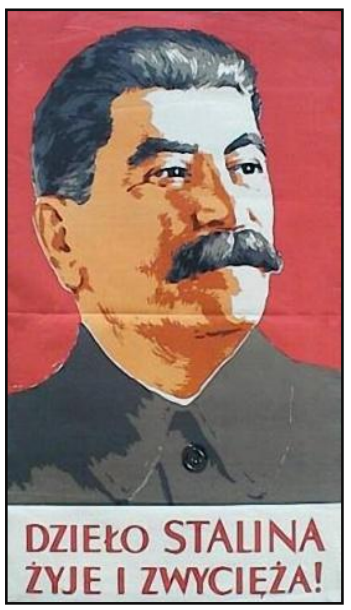

Plakat 27

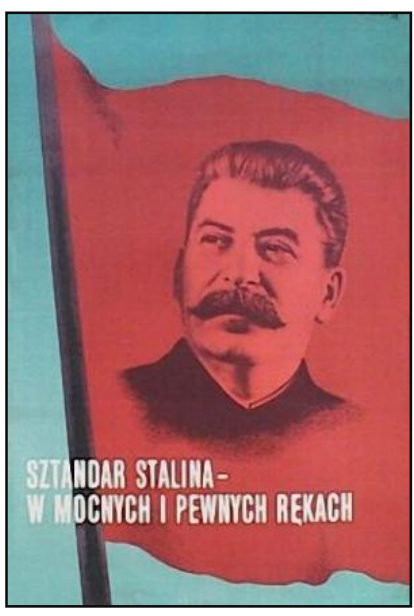

Plakat 28

Propaganda nie pomijała również kwestii wizerunku państwowych władz komunistycznych. Kreacja wizerunku władz ludowych odbywała się często poprzez sposób prezentacji przeciwników politycznych i „wrogów narodu". Propagandowa krytyka wroga automatycznie wiązała się z przypisaniem sobie cech przeciwstawnych. Dobrym przykładem zasto- 
sowania chwytu tego typu jest plakat Olbrzym $i$ zapluty karzet reakcji jeden z najbardziej znanych i najczęściej reprodukowanych posterów z okresu 1944-1956 (plakat 16). Zarówno tekst, jak i obraz tworzyły na nim proste opozycje: olbrzym - karzeł, siły władz ludowych - reprezentant Armii Krajowej. Treść wizualna pogłębiała deprecjację wroga, zobrazowanego w postaci karła i jednocześnie podnosiła rangę sił komunistycznych, ilustrując je w osobie rosłego, budzącego zaufanie żołnierza Armii Ludowej.

Nieodłącznym elementem analizowanych plakatów był tekst. W zależności od wyrażanych treści propagandowych obraz zawsze uzupełniały różne hasła, slogany oraz podpisy. Praktycznie nie pojawiały się postery, na których treść obrazowa nie byłaby wspierana przez słowo. Krótkie i chwytliwe hasła czy slogany są jednym z podstawowych elementów wszelkiego rodzaju perswazji zarówno tej w komunikatach reklamowych, jak i w propagandzie politycznej. Konstrukcja sloganu, oparta na skondensowanej treści, jest jednym z czynników warunkujących skuteczność jego oddziaływania. Dobrze funkcjonujący slogan cechuje się ponadto treścią zrozumiałą dla szerokiego grona odbiorców - łatwość odczytania informacji ułatwia jej zapamiętanie. Hasła propagandowe często odwołują się również do emocji - dzięki temu efektywnie mogą pełnić wielorakie funkcje: wezwania do określonej aktywności, objaśnienia lub przestrogi. Przykładami wymienionych funkcji tekstu na plakatach komunistycznych mogą być: propagujący konkretne decyzje wyborcze plakat Głosuj 3 razy tak (plakat 13), wyjaśniający rolę armii poster Żołnierz polski i radziecki przynieśli wolność naszej ojczyźnie (plakat 9) bądź ostrzegający przed wrogiem obraz Bądź czujny (plakat 24). Wielokrotnie slogany pełniły kilka funkcji jednocześnie, jak na plakacie Nie chcesz powrotu kapitalistów - głosuj trzy razy tak (plakat 22), gdzie mamy do czynienia zarówno z przestroga, jak i zaleceniem. Odwołania do tekstu ułatwiały nadawanie jasnych, jednoznacznych komunikatów i zwiększały czytelność informacji przedstawionych za pomocą obrazu. W ten sposób słowo potęgowało skuteczność oddziaływania propagandy.

Kwestia obecności i rodzaju kolorystyki na analizowanych pracach była ostatnią kategorią badawczą. Barwa stanowi konstytutywny element każdego plakatu, dlatego jej użycie nie może być przypadkowe. Każdy kolor ma specyficzne właściwości, dzięki którym może budować określony nastrój, wywoływać pożądane emocje i skojarzenia. Świadome zastosowanie danej kolorystyki w znacznym stopniu wpływa więc na skuteczność oddziaływania propagandy wizualnej. 
Propagandziści komunistyczni chętnie posługiwali się kolorem - jedynie trzy plakaty w wyodrębnionym zestawie stanowią proste, czarno-białe grafiki. Plakaty, w zależności od przekazywanych na nich treści, różniły się zastosowaną tonacją barw. Prace definiujące i piętnujące wroga często pozbawione były koloru lub utrzymane $\mathrm{w}$ ciemniejszych barwach (plakaty 17, 19, 20, 22, 23, 24). Z kolei plakaty o innej tematyce prezentujące władzę ludową bądź motywujące do konkretnych działań odznaczały się szerszą paletą barw, w bardziej „optymistycznej” tonacji (plakaty $1,8,9,26$ ). Ponieważ wizualne przekazy propagandowe wykorzystywały elementy polskiej i radzieckiej symboliki narodowej, często pojawiającą się na plakatach barwą był kolor czerwony.

\section{Podsumowanie}

Tekst skupia się przede wszystkim na interpretacji komunistycznych plakatów przez pryzmat obecnego na nich motywu walki. Ponieważ walka w propagandzie komunistycznej stała się metaforą działania w wielu obszarach życia społecznego, wątki militarne pojawiają się nie tylko na plakatach wymierzonych we wrogów systemu czy propagujących służbę wojskową.

Paradoksalnie, najmniej motywów walki oraz agresywnego tonu towarzyszy przedstawieniom żołnierzy Wojska Ludowego i „sprzymierzonej" z nim Armii Czerwonej. Żołnierz na plakacie komunistycznym to wyzwoliciel, bohater, przyjaciel ludu (plakaty 3, 9, 10, 11). Choć jego praca polegała przecież na rzeczywistych starciach i czynach zbrojnych, prezentowany był najczęściej w warunkach pokojowych - jako triumfator i zwycięzca.

Znamion walki $\mathrm{w}$ propagandzie władz ludowych nabrała za to praca, której wizualne przedstawienia znajdywały egzemplifikacje w wojowniczych pozach socjalistycznych ludzi pracy. Symboliczne przedstawienie pracy jako walki wyraźnie sugerowała przyjmowana przez robotników postawa oraz narzędzia imitujące broń (plakaty 2, 6, 7). Stylizację pracy robotniczej jako działań bojowych uzupełniały umieszczane na plakatach hasła w stylu „Naprzód! Do walki o plan 6-letni!” (plakat 2) czy „Wykonamy z honorem zadania 1955 roku” (plakat 7). Podobne wrażenia rodzi plakat Nie damy ziemi obszarnikom (plakat 1), na którym postawa chłopów czy wyrazy ich twarzy świadczą o gotowości do kon- 
frontacji z wrogiem, także siłowej. Słowo „walka” jako synonim pojęcia "pracy” prezentuje także plakat 5. Propagandziści wprost nawołują tu do „Walki o szczęśliwą socjalistyczną wieś polską". Treść plakatu skierowana jest do młodych kobiet, których mobilizacja, w wymiarze zawodowym, oznacza swego rodzaju militaryzację, wezwanie do uczestnictwa we wspólnych zmaganiach towarzyszących budowie nowej Polski.

Oczywiste odwołania do walki zarówno w wymiarze politycznym, jak i zbrojnym pojawiają się $\mathrm{w}$ propagandzie wymierzonej we wroga. Walka z przeciwnikiem odbywa się tu zwłaszcza w warstwie językowejkomuniści deprecjonują swoich przeciwników, nadając im etykiety zdrajców, faszystów, "zaplutych karłów reakcji”, kułaków, wyzyskiwaczy, obszarników, imperialistów oraz zachłannych kapitalistów (plakaty 1325). Polityczno-propagandowy żargon - przesiąknięty mową nienawistną - był charakterystyczny dla nieustającej walki polityczno-klasowej prowadzonej przez komunistów.

Inwazyjny charakter plakatów propagandowych intensyfikowała jeszcze inna, znamienna cecha ich zastosowania, a mianowicie - wszechobecność. Plakaty komunistyczne atakowały nie tylko treścią; nie tylko odnosiły tę treść do niemal każdej sfery życia. Dodatkowo silnie ingerowały w przestrzeń fizyczna, totalnie ją opanowując. Były więc wszędzie w zakładach pracy, w szkołach, na ulicach. Nachalna wręcz obecność plakatów miała oczywiście potęgować skuteczność ich oddziaływania. Ocena realnego wpływu treści propagandowych na społeczeństwo jest jednak trudna oraz wymaga dużo głębszych analiz i badań. Pewne jest natomiast, że odczuwane i zauważane było wszędobylstwo plakatów, któremu Jan Brzechwa poświęcił satyryczny wiersz:

\author{
[...] Wisi plakat przy plakacie, \\ wciąż te same trzy postacie, \\ trzy tułowie, trzy prawice \\ zdobią place i ulice. [...] \\ A przechodnie myślą: „Psiakość! \\ Nie przechodzi ilość w jakość" (Marianowicz 1955: 29).
}

Ten kontekst rozważań dotyczących plakatów potwierdza słuszność tezy, przytoczonej za Szulczewskim we wstępie, która wskazuje na siły zbrojne i propagandę jako dwa główne środki działania $w$ państwie. $\mathrm{W}$ pewnym sensie analiza motywów militarnych dodatkowo pogłębia tę intuicje - walka i propaganda, dwa rodzaje aktywności, zostały sprzęgnięte razem, zapętliły się. W latach 1944-1956 to sprzężenie wydaje się 
szczególnie wyraziste. Dobitnie potwierdza to dokumentacja wydarzeń naznaczonych piętnem przemocy oraz intensywna działalność propagandowa, której plakatowe przykłady analizowano powyżej. W polityce władz komunistycznych walka wypełniała więc treści propagandowe, propaganda zaś stała się narzędziem walki.

\section{Bibliografia}

Czyżniewski, M., (2005), Propaganda polityczna władzy ludowej w Polsce 1944-1956. Toruń: Wydawnictwo Naukowe Grado.

Ferenc, T., (2007), Analiza obrazów - przegląd metod i inspiracji teoretycznych, "Acta Universitatis Lodziensis. Folia Sociologica", nr 32.

Izdebski, J., (2000), Bądź czujny: Plakat i grafika w stużbie propagandy komunistycznej 19441956. Rzeszów: Instytut Pamięci Narodowej - KŚZpNP Biuro Edukacji Publicznej Oddział w Rzeszowie, Poligrafia Wyższego Seminarium Duchownego.

Jung, C. G., (1976), Archetypy i symbole. Pisma wybrane. Warszawa: Wydawnictwo Czytelnik.

Kamiński, Ł., (2004), Struktury propagandy w PRL, [w:] P. Semkow (red.), Propaganda PRL. Wybrane problemy. Gdańsk: IPN Komisja Ścigania Zbrodni Przeciwko Narodowi Polskiemu.

Marianowicz, A., (1955), Antologia satyry polskiej 1944-1955. Warszawa: Państwowy Instytut Wydawniczy.

Roszkowski, W., (2006), Historia Polski 1914-2005. Warszawa: Wydawnictwo Naukowe PWN.

Szulczewski, M., (1972), Propaganda polityczna. Zarys problematyki teoretycznej. Warszawa: Książka i Wiedza.

Znaniecki, F., (1990), Wspótczesne narody. Warszawa: Państwowe Wydawnictwo Naukowe.

http://pl.wikisource.org/wiki/Manifest_Polskiego_Komitetu_Wyzwolenia_Narodowego http://chomikuj.pl/zamorski/*e2*99*a0Plakaty*e2*99*a0/Plakat+polityczny+PRL

http://www.prl.cba.pl/plakaty.html

\section{Informacje na temat wykorzystanych w pracy plakatów:}

\section{Plakat 1}

Autor: nieustalony, 1946

Tytuł: Nie damy ziemi obszarnikom. Nie damy fabryk i kopalń kapitalistom

\section{Plakat 2}

Autor: Włodzimierz Zakrzewski, 1949

Tytuł: NAPRZÓD! Do walki o plan 6-letni! 


\section{Plakat 3}

Autor: Włodzimierz Zakrzewski, 1944

Tytuł: Wypróbowani w bojach. Na straży granic i demokracji

\section{Plakat 4}

Autor: Wojciech Fangor, Jerzy Tchorzewski, 1953

Tytuł: Pozdrawiamy kobiety pracujace dla pokoju i rozkwitu ojczyzny!

\section{Plakat 5}

Autor: Witold Chmielewski, 1951

Tytuł: MŁODZIEŻY - naprzód do walki o szczęśliwa socjalistyczna wieś polska

\section{Plakat 6}

Autor: Włodzimierz Zakrzewski, 1950

Tytuł: Wkraczamy w plan 6-letni

\section{Plakat 7}

Autor: Tadeusz Jodłowski, 1955

Tytuł: Wykonamy z honorem zadania 1955 roku

\section{Plakat 8}

Autor: (?) Oracz, 1946

Tytuł: Nad Odrę po ziemię ojców i dobrobyt

\section{Plakat 9}

Autor: Władysław Janiszewski, 1951

Tytuł: Żotnierz radziecki i polski przynieśli wolność naszej ojczyźnie

\section{Plakat 10}

Autor: Stefan Wielgus, Wydawnictwo Ministerstwa Obrony Narodowej, 1951

Tytuł: Radość i duma rodziców

\section{Plakat 11}

Autor: Tadeusz Trepkowski, 1954

Tytuł: Na straży pokojowego życia narodu

\section{Plakat 12}

Autor: nieustalony, b.d.

Tytuł: Blok demokratyczny to najmocniejszy stup graniczny

\section{Plakat 13}

Autor: nieustalony, Wojskowy Urząd Informacji i Propagandy, 1946

Tytuł: Głosuj 3 razy tak

\section{Plakat 14}

Autor: nieustalony, 1946

Tytuł: TAK TAK TAK

\section{Plakat 15}

Autor: Olga Siemaszkowa, Eryk Lipiński, Mieczysław Piotrowski, 1946

Tytuł: Wyszło szydło z worka 
Plakat 16

Autor: Włodzimierz Zakrzewski

Tytuł: Olbrzym i zapluty karzet reakcji

Plakat 17

Autor: nieustalony, po 1945

Tytuł: Z faszyzmu Polskę oczyścimy

Plakat 18

Autor: Stefan Wielgus, 1953

Tytuł: „Dobry” kutak

\section{Plakat 19}

Autor: nieustalony, WZGraf., Warszawa, Pracownia "Szpilek”, 1950

Tytuł: Bruderszaft

\section{Plakat 20}

Autor: nieustalony, 1950

Tytuł: Udław się!...

\section{Plakat 21}

Autor: nieustalony, 1950

Tytuł: Imperializm amerykański chce panować nad światem

\section{Plakat 22}

Autor: Mieczysław Berman, Juliusz Krajewski,1946

Tytuł: Nie chcesz powrotu kapitalistów - głosuj trzy razy tak

\section{Plakat 23}

Autor: Maria Konstanty Sopoćko, 1956-1963

Tytuł: Strzeż tajemnicy stużbowej

\section{Plakat 24}

Autor: Tadeusz Trepkowski, 1945

Tytuł: Bądź czujny wobec wroga narodu

\section{Plakat 25}

Autor: Wojciech Fangor, Stołeczne Zakłady Graficzne nr 3, Warszawa 1951

Tytuł: Strzeż tajemnicy państwowej

\section{Plakat 26}

Autor: nieustalony, b.d.

Tytuł: Przyjaźń polsko-radziecka to pokój. Niezawistość. Szczęśliwe jutro naszej ojczyzny

\section{Plakat 27}

Autor: Włodzimierz Zakrzewski, 1953

Tytuł: Dzieło Stalina żyje i zwycięża!

\section{Plakat 28}

Autor: Tadeusz Trepkowski, 1953

Tytuł: Sztandar Stalina w mocnych i pewnych rękach 
W latach 1944-1945 większość plakatów powstała w Pracowni Plakatów Propagandowych przy Głównym Zarządzie Polityczno-Wychowawczym Wojska Polskiego w Lublinie. Z początkiem 1945 r. Pracownia Plakatów Propagandowych przeniosła się do Łodzi. W połowie $1945 \mathrm{r}$. powstała Agencja Propagandy Artystycznej w Warszawie. W 1950 r. w odpowiedzi na rosnące zapotrzebowanie na propagandę wizualną utworzono Wydawnictwo Artystyczne i Graficzne RSW „Ruch” pod nadzorem Ministerstwa Kultury i Sztuki*.

* J. Izdebski, Plakat w stużbie propagandy 1944-1956, „Biuletyn Instytutu Pamięci Narodowej" 2001, nr 11, s. 72-73. 